\title{
Evaluation of Isotopic Abundance Ratio and Structural Properties of Magnesium Gluconate After Treatment with the Energy of Consciousness Using LC-MS and NMR Spectroscopy
}

\author{
Mahendra Kumar Trivedi ${ }^{1}$, Alice Branton ${ }^{1}$, Dahryn Trivedi ${ }^{1}$, Gopal Nayak ${ }^{1}$, \\ Cathryn Dawn Nykvist ${ }^{1}$, Celine Lavelle ${ }^{1}$, Daniel Paul Przybylski ${ }^{1}$, Dianne Heather Vincent ${ }^{1}$, \\ Dorothy Felger ${ }^{1}$, Douglas Jay Konersman ${ }^{1}$, Elizabeth Ann Feeney ${ }^{1}$, Jay Anthony Prague ${ }^{1}$, \\ Joanne Lydia Starodub ${ }^{1}$, Karan Rasdan ${ }^{1}$, Karen Mie Strassman ${ }^{1}$, Leonid Soboleff ${ }^{1}$, \\ Maire Anne Mayne ${ }^{1}$, Mary M. Keesee ${ }^{1}$, Padmanabha Narayana Pillai ${ }^{1}$, Pamela Clarkson Ansley ${ }^{1}$, \\ Ronald David Schmitz ${ }^{1}$, Sharyn Marie Sodomora ${ }^{1}$, Kalyan Kumar Sethi ${ }^{2}$, Parthasarathi Panda ${ }^{2}$, \\ Snehasis Jana ${ }^{2}$, \\ ${ }^{1}$ Trivedi Global, Inc., Henderson, Nevada, USA \\ ${ }^{2}$ Trivedi Science Research Laboratory Pvt. Ltd., Bhopal, Madhya Pradesh, India
}

Email address:

publication@trivedieffect.com (S. Jana)

${ }^{*}$ Corresponding author

To cite this article:

Mahendra Kumar Trivedi, Alice Branton, Dahryn Trivedi, Gopal Nayak, Cathryn Dawn Nykvist, Celine Lavelle, Daniel Paul Przybylski, Dianne Heather Vincent, Dorothy Felger, Douglas Jay Konersman, Elizabeth Ann Feeney, Jay Anthony Prague, Joanne Lydia Starodub, Karan Rasdan, Karen Mie Strassman, Leonid Soboleff, Maire Anne Mayne, Mary M. Keesee, Padmanabha Narayana Pillai, Pamela Clarkson Ansley, Ronald David Schmitz, Sharyn Marie Sodomora, Kalyan Kumar Sethi, Parthasarathi Panda, Snehasis Jana. Evaluation of Isotopic Abundance Ratio and Structural Properties of Magnesium Gluconate After Treatment with the Energy of Consciousness Using LC-MS and NMR Spectroscopy. Advances in Bioscience and Bioengineering. Vol. 5, No. 1, 2017, pp. 1-11. doi: 10.11648/j.abb.20170501.11

Received: January 31, 2017; Accepted: February 13, 2017; Published: February 25, 2017

Abstract: The current research work was aimed to investigate the impact of The Trivedi Effect ${ }^{\circledR}$ - Energy of Consciousness Healing Treatment (Biofield Energy Healing) on the structural properties and isotopic abundance ratio $\left(\mathrm{P}_{\mathrm{M}+1} / \mathrm{P}_{\mathrm{M}}\right)$ of magnesium gluconate using LC-MS and NMR spectroscopy. Magnesium gluconate was divided into two parts. One part was denoted as the control, while the another part was defined as The Trivedi Effect ${ }^{\circledR}$ Treated sample, which received the Biofield Energy Healing Treatment remotely from eighteen renowned Biofield Energy Healers. The total ion chromatogram of the control sample showed two peaks at $\mathrm{R}_{\mathrm{t}}$ of 1.81 and 2.06 min, whereas the treated sample displayed peaks at $\mathrm{R}_{\mathrm{t}}$ of 1.79 and $2.04 \mathrm{~min}$. The ESI-MS spectra of the control and the treated samples revealed the presence of the mass for magnesium gluconate ion in two forms at $\mathrm{m} / \mathrm{z} 447$ (adduct form with methanol) and 415 (protonated ion) in positive ionization mode. But, it showed the mass for the gluconate ion at $\mathrm{m} / \mathrm{z} 195$ in the negative ionization mode. The fragmentation pattern of magnesium gluconate in the treated sample was notably altered compared with the control sample. The proton and carbon signals for $\mathrm{CH}, \mathrm{CH}_{2}$ and $\mathrm{CO}$ groups in the proton and carbon $\mathrm{NMR}$ spectra were found almost similar for the control and treated samples. The LC-MS based isotopic abundance ratio analysis indicated that the $\mathrm{P}_{\mathrm{M}+1} / \mathrm{P}_{\mathrm{M}}\left({ }^{2} \mathrm{H} /{ }^{1} \mathrm{H}\right.$ or ${ }^{13} \mathrm{C} /{ }^{12} \mathrm{C}$ or ${ }^{17} \mathrm{O} /{ }^{16} \mathrm{O}$ or $\left.{ }^{25} \mathrm{Mg} /{ }^{24} \mathrm{Mg}\right)$ in the treated magnesium gluconate ion at $\mathrm{m} / \mathrm{z} 415$ was significantly decreased by $79.24 \%$ compared with the control sample. Similarly, the isotopic abundance ratio of $\mathrm{P}_{\mathrm{M}+1} / \mathrm{P}_{\mathrm{M}}\left({ }^{2} \mathrm{H} /{ }^{1} \mathrm{H}\right.$ or ${ }^{13} \mathrm{C} /{ }^{12} \mathrm{C}$ or $\left.{ }^{17} \mathrm{O} /{ }^{16} \mathrm{O}\right)$ in the gluconate ion was decreased by $6.62 \%$ in the treated sample compared with the control sample. The treated magnesium gluconate might be beneficial in the nutraceutical and/or pharmaceutical industries for designing various forms of formulations, which could be providing better therapeutic response against various diseases such as diabetes mellitus, allergy, aging, inflammatory diseases, immunological disorders, and other chronic infections. Consequently, The Trivedi Effect ${ }^{\circledR}$ - Energy of Consciousness Healing Treated 
magnesium gluconate would be more helpful for understanding the enzymatic reactions as well as assist in the designing of the novel potent enzyme inhibitors by applying its kinetic isotope effects.

Keywords: Biofield Energy Healing Treatment, Energy of Consciousness Healing Treatment, Biofield Energy Healers, The Trivedi Effect ${ }^{\circledR}$, Magnesium Gluconate, LC-MS, NMR, Isotopic Abundance Ratio, Isotope Effects

\section{Introduction}

Magnesium ion $\left(\mathrm{Mg}^{2+}\right)$ is a major intracellular divalent cation and an essential mineral for several enzymes, DNA and RNA synthesis, reproduction and protein synthesis. It is also a vital coherent controller of glycolysis and the Krebs cycle $[1,2]$. Magnesium gluconate $\left(\mathrm{C}_{12} \mathrm{H}_{22} \mathrm{MgO}_{14}\right)$ is the organometallic salt of magnesium with gluconic acid produced from glucose catalyzed by glucose oxidase [3]. Magnesium gluconate is found to be a more powerful antioxidant than other magnesium salts and it is useful for the prevention and treatment of many diseases such as cardiovascular diseases, diabetes mellitus, allergy, inflammatory diseases, immunological disorders, Alzheimer's disease, asthma, pre-eclampsia and eclampsia, cancer, etc. [4-8]. It can be used as neuroprotective [9], for the treatment of oxidative stress induced ischemia/reperfusion injury [10] and also labor in women arrested initially with intravenous therapy as an oral tocolytic agent [11]. Magnesium gluconate showed the highest bioavailability and most physiologically acceptable salt among other magnesium salts like chloride, sulfate, carbonate, acetate, citrate, lactate, aspartate, etc. [8, 12]. Therefore, magnesium gluconate was considered as one of the components in a novel proprietary herbomineral formulation for the source of magnesium ion. This herbomineral formulation which is designed as nutraceutical supplement can be used for the prevention and treatment of various human diseases.

Since ancient times, many different cultures, religions and systems of belief have recognized a living force that preserves and inhabits every living organism. This force is the source of 'life' and has been called various names, such as prana by the Hindus, qi or chi by the Chinese, and $k i$ by the Japanese. This is believed to co-relate with the soul, spirit and mind. This hypothetical vital force has been scientifically evaluated and is now considered the Bioenergetics Field. The Biofield Energy is a dynamic electromagnetic field surrounding the human body, resulting from the continuous emission of low-level light, heat, and acoustical energy from the body. Biofield Energy is infinite, para dimensional and can freely flow between the human and environment [13, 14]. So, a human has the ability to harness energy from the ionosphere of the earth, the "universal energy field", and transmit it to any living organism (s) or nonliving object (s) around the globe. The object or recipient always receives the energy and responds in a useful way. This process is known as The Trivedi Effect ${ }^{\mathbb{B}}$ - Biofield Energy Healing Treatment $[15,16]$. Biofield (Putative Energy
Field) based Energy Therapies are used worldwide to promote health and healing. The National Center of Complementary and Integrative Health $(\mathrm{NCCIH})$ has recognized and accepted Biofield Energy Healing as a Complementary and Alternative Medicine (CAM) health care approach in addition to other therapies, medicines and practices such as natural products, deep breathing, yoga, Tai Chi, Qi Gong, chiropractic/osteopathic manipulation, meditation, massage, special diets, homeopathy, progressive relaxation, guided imagery, acupressure, acupuncture, relaxation techniques, hypnotherapy, healing touch, movement therapy, pilates, rolfing structural integration, mindfulness, Ayurvedic medicine, traditional Chinese herbs and medicines, naturopathy, essential oils, aromatherapy, Reiki, cranial sacral therapy and applied prayer (as is common in all religions, like Christianity, Hinduism, Buddhism and Judaism) [17]. Biofield Energy Treatment (The Trivedi Effect $\left.^{\circledR}\right)$ has been extensively studied with significant outcomes in many scientific fields such as agriculture [1820], biotechnology [21-23], materials science [24-28], pharmaceutical sciences [29-31], medical science [32, 33], and microbiology [34-36]. Literature demonstrated that Biofield Energy Healing Treatment (The Trivedi Effect ${ }^{\circledR}$ ) might be an alternative method for increasing or decreasing the natural isotopic abundance ratio of the substances $[37,38]$. The stable isotope ratio analysis has the wide applications in several scientific fields for understanding the isotope effects resulting from the variation of the isotopic composition of the molecule [39, 40]. Conventional mass spectrometry (MS) techniques such as liquid chromatography - mass spectrometry (LCMS), gas chromatography - mass spectrometry (GC-MS) are widely used for isotope ratio analysis with sufficient precision [41]. Hence, LC-MS and NMR (Nuclear Magnetic Resonance) were used in this study to characterize the structural properties of the Biofield Energy Treated and untreated magnesium gluconate qualitatively for the purpose of the pharmaceutical and nutraceutical industrial applications. Consequently, LCMS based isotopic abundance ratio analysis of $\mathrm{P}_{\mathrm{M}+1} / \mathrm{P}_{\mathrm{M}}$ $\left({ }^{2} \mathrm{H} /{ }^{1} \mathrm{H}\right.$ or ${ }^{13} \mathrm{C} /{ }^{12} \mathrm{C}$ or ${ }^{17} \mathrm{O} /{ }^{16} \mathrm{O}$ or $\left.{ }^{25} \mathrm{Mg} /{ }^{24} \mathrm{Mg}\right)$ in both of the Biofield Energy Treated and untreated samples was targeted to evaluate the influence of Biofield Energy Healing Treatment on the isotopic abundance ratio in magnesium gluconate. 


\section{Materials and Methods}

\subsection{Chemicals and Reagents}

Magnesium gluconate hydrate was procured from Tokyo Chemical Industry Co., Ltd. (TCI), Japan. All other chemicals used in the experiment were of analytical grade available in India.

\subsection{Energy of Consciousness Treatment Strategies}

Magnesium gluconate was one of the components of the new proprietary herbomineral formulation, which was developed by our research team and was used per se as the test compound for the current study. The test compound was divided into two parts. One part of the test compound did not receive any sort of treatment and defined as untreated or control magnesium gluconate sample. Consequently, another part of the test compound was treated with The Trivedi Effect ${ }^{\circledR}$ - Energy of Consciousness Healing Treatment remotely by eighteen renowned Biofield Energy Healers and defined as Biofield Energy Treated magnesium gluconate. Eleven of the Biofield Energy Healers were located in the U. S. A., four in Canada, one in Ireland, one in the United Kingdom, and one in Russia performed the Biofield Energy Treatment on the test compound that was located in the research laboratory of GVK Biosciences Pvt. Ltd., Hyderabad, India. The Biofield Energy Treatment was provided for 5 minutes through the Healer's Unique Energy Transmission process remotely to the test compound, which was kept under laboratory conditions. None of the Biofield Energy Healers in this study visited the laboratory in person, nor had any contact with the compounds. Similarly, the control compound was subjected to a "sham" healer for 5 minutes, under the same laboratory conditions. The sham healer did not have any knowledge about the Biofield Energy Treatment. After that, the Biofield Energy Treated and untreated samples were kept in similar sealed conditions. The control and Biofield Energy Treated samples were analyzed by LC-MS and NMR spectroscopy.

\subsection{Characterization}

\subsubsection{Liquid Chromatography-Mass Spectrometry (LC-MS) Analysis}

Liquid chromatography was accomplished using The Waters ${ }^{\circledR}$ ACQUITY UPLC, Milford, MA, USA equipped with a binary pump (The Waters ${ }^{\circledR}$ BSM HPLC pump), autosampler, column heater and a photo-diode array (PDA) detector. The column used for the study was a reversed phase Acquity BEH shield RP C18 (150 X $3.0 \mathrm{~mm}, 2.5$ $\mu \mathrm{m})$. The column temperature was kept constant at $40^{\circ} \mathrm{C}$. The mobile phase was $2 \mathrm{mM}$ ammonium acetate in water as mobile phase A and acetonitrile as mobile phase B. Chromatographic separation was achieved with the following gradient program: 0 minute $-5 \% \mathrm{~B}$; 1 minute $5 \% \mathrm{~B} ; 15$ minutes - 97\%B; 20 minutes - 97\%B; 21 minutes
- 5\%B; 25 minutes $-5 \% \mathrm{~B}$. The flow rate was at a constant flow rate of $0.4 \mathrm{~mL} /$ minutes. The control and Biofield Energy Treated samples were dissolved in a mixture of water and methanol $(60: 40 \mathrm{v} / \mathrm{v})$ to prepare a $1 \mathrm{mg} / \mathrm{mL}$ stock solution. An aliquot of $2 \mu \mathrm{L}$ of the stock solution was used for analysis by LC-ESI-MS and the total run time was 25 minutes.

Mass spectrometric analysis was accompanied on a Triple Quad (Waters Quattro Premier XE, USA) mass spectrometer equipped with an electrospray ionization (ESI) source with the following parameters: electrospray capillary voltage $3.5 \mathrm{kV}$; source temperature $100^{\circ} \mathrm{C}$; desolvation temperature $350^{\circ} \mathrm{C}$; cone voltage $30 \mathrm{~V}$; desolvation gas flow $1000 \mathrm{~L} / \mathrm{h}$ and cone gas flow $60 \mathrm{~L} / \mathrm{h}$. Nitrogen was used in the electrospray ionization source. The multiplier voltage was set at $650 \mathrm{~V}$. LC-MS was taken in positive and negative ionization mode and with the full scan $(m / z 50-1400)$. The total ion chromatogram, peak area $\%$ and mass spectrum of the individual peak (appeared in LC) were recorded.

\subsubsection{Isotopic Abundance Ratio Analysis}

The isotopic abundance ratio of the control and Biofield Energy Treated magnesium gluconate was performed. The natural abundance of each isotope can be predicted from the comparison of the height of the isotope peak with respect to the base peak, i.e. relative abundance in the mass spectra [37, $38,42,43]$. The natural isotopic abundance of the elements are obtained from several literatures [43-45] are presented in Table 1.

Table 1. The isotopic composition (the natural isotopic abundance) of the elements.

\begin{tabular}{|c|c|c|c|c|c|}
\hline Element $(A)$ & Symbol & Mass & $\begin{array}{l}\% \text { Natural } \\
\text { Abundance }\end{array}$ & $A+1$ Factor & $A+2$ Factor \\
\hline \multirow[t]{2}{*}{ Hydrogen } & ${ }^{1} \mathrm{H}$ & 1 & 99.9885 & & \\
\hline & ${ }^{2} \mathrm{H}$ & 2 & 0.0115 & $0.015 \mathrm{n}_{\mathrm{H}}$ & \\
\hline \multirow[t]{2}{*}{ Carbon } & ${ }^{12} \mathrm{C}$ & 12 & 98.892 & & \\
\hline & ${ }^{13} \mathrm{C}$ & 13 & 1.108 & $1.1 \mathrm{n}_{\mathrm{C}}$ & \\
\hline \multirow[t]{3}{*}{ Oxygen } & ${ }^{16} \mathrm{O}$ & 16 & 99.762 & & \\
\hline & ${ }^{17} \mathrm{O}$ & 17 & 0.038 & $0.04 \mathrm{n}_{\mathrm{O}}$ & \\
\hline & ${ }^{18} \mathrm{O}$ & 18 & 0.200 & & $0.20 \mathrm{n}_{\mathrm{O}}$ \\
\hline \multirow[t]{3}{*}{ Magnesium } & ${ }^{24} \mathrm{Mg}$ & 24 & 78.99 & & \\
\hline & ${ }^{25} \mathrm{Mg}$ & 25 & 10.00 & $12.66 \mathrm{n}_{\mathrm{Mg}}$ & \\
\hline & ${ }^{26} \mathrm{Mg}$ & 26 & 11.01 & & $13.94 \mathrm{n}_{\mathrm{Mg}}$ \\
\hline
\end{tabular}

A: Element; n: no of $\mathrm{H}, \mathrm{C}, \mathrm{O}, \mathrm{Mg}$, etc.

The following method was used for calculating the isotopic abundance ratio:

$P_{M}$ stands for the relative peak intensity of the parent molecular ion $\left[\mathrm{M}^{+}\right]$expressed in percentage. In other way, it indicates the probability to have $A$ element (for $e . g .{ }^{12} \mathrm{C},{ }^{1} \mathrm{H}$, ${ }^{16} \mathrm{O},{ }^{24} \mathrm{Mg}$, etc.) contributions to the mass of the parent 
molecular ion $\left[\mathrm{M}^{+}\right]$.

$\mathrm{P}_{\mathrm{M}+1}$ represents the relative peak intensity of the isotopic molecular ion $\left[(\mathrm{M}+1)^{+}\right]$expressed in percentage

$=\left(\right.$ no. of $\left.{ }^{13} \mathrm{C} \times 1.1 \%\right)+\left(\right.$ no. of $\left.{ }^{2} \mathrm{H} \times 0.015 \%\right)+\left(\right.$ no. of ${ }^{17} \mathrm{O}$ x $0.04 \%)+\left(\right.$ no. of ${ }^{25} \mathrm{Mg}$ x $12.66 \%$ )

i.e. the probability to have $A+1$ element (for e.g. ${ }^{13} \mathrm{C},{ }^{2} \mathrm{H}$, ${ }^{25} \mathrm{Mg}$, etc.) contributions to the mass of the isotopic molecular ion $\left[(\mathrm{M}+1)^{+}\right]$

$\mathrm{P}_{\mathrm{M}+2}$ represents the relative peak intensity of the isotopic molecular ion $\left[(\mathrm{M}+2)^{+}\right]$expressed in the percentage

$=\left(\right.$ no. of $\left.{ }^{18} \mathrm{O} \times 0.20 \%\right)+\left(\right.$ no. of $\left.{ }^{26} \mathrm{Mg} \times 13.94 \%\right)$

i.e. the probability to have $A+2$ elements (for $e . g .{ }^{18} \mathrm{O}$, ${ }^{26} \mathrm{Mg}$, etc.) contributions to the mass of isotopic molecular ion $\left[(\mathrm{M}+2)^{+}\right]$

Isotopic abundance ratio (IAR) for $A+1$ elements $=\mathrm{P}_{\mathrm{M}}+$ ${ }_{1} / \mathrm{P}_{\mathrm{M}}$

Similarly, isotopic abundance ratio of $A+2$ elements $=$ $\mathrm{P}_{\mathrm{M}+2} / \mathrm{P}_{\mathrm{M}}$

Percentage $(\%)$ change in isotopic abundance ratio $=$

$\left.\left[\left(\mathrm{IAR}_{\text {Treated }}-\mathrm{IAR}_{\text {Control }}\right) / \mathrm{IAR}_{\text {Control }}\right) \times 100\right]$

Where, $\mathrm{IAR}_{\text {Treated }}$ is isotopic abundance ratio in the treated magnesium gluconate sample and $\mathrm{IAR}_{\text {Control }}$ is isotopic abundance ratio in the control magnesium gluconate sample.

\subsubsection{Nuclear Magnetic Resonance (NMR) Analysis}

${ }^{1} \mathrm{H}$ NMR spectra were recorded in a $400 \mathrm{MHZ}$ VARIAN

FT-NMR spectrometer at room temperature. Data refer to

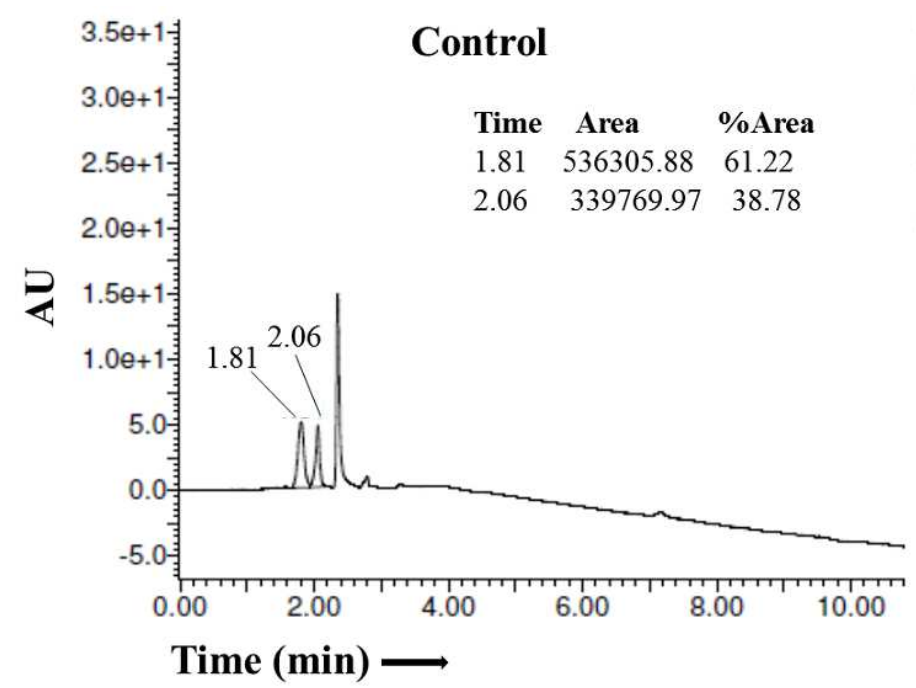

solutions in $\mathrm{D}_{2} \mathrm{O}$ with the residual solvent protons as internal references. ${ }^{1} \mathrm{H}$ NMR multiplicities were designated as singlet (s), doublet (d), triplet (t), multiplet $(\mathrm{m})$, and broad (br). ${ }^{13} \mathrm{C}$ NMR spectra were measured at $100 \mathrm{MHz}$ on a VARIAN FT-NMR spectrometer at room temperature. Chemical shifts $(\delta)$ were in parts per million (ppm) relative to the solvent's residual proton chemical shift $\left(\mathrm{D}_{2} \mathrm{O}, \delta=4.65 \mathrm{ppm}\right)$ and solvent's residual carbon chemical shift $\left(\mathrm{D}_{2} \mathrm{O}, \delta=0 \mathrm{ppm}\right)[46]$.

\section{Results and Discussion}

\subsection{Liquid Chromatography-Mass Spectrometry (LC-MS) Analysis}

The total ion chromatograms (TIC) of the control and Biofield Energy Treated magnesium gluconate are shown in Figure 1. The TIC of the control magnesium gluconate showed two peaks at retention time $\left(\mathrm{R}_{\mathrm{t}}\right)$ of 1.81 and 2.06 minutes with the peak area\% of $61.22 \%$ and $38.78 \%$, respectively in the chromatogram. Similarly, the chromatogram of the Biofield Energy Treated magnesium gluconate exhibited two peaks at $\mathrm{R}_{\mathrm{t}}$ of 1.79 and $2.04 \mathrm{~min}$ with the peak area $\%$ of $61.77 \%$ and $38.23 \%$, respectively. The results indicated that Biofield Energy did not show any impact in the alteration of the polarity/affinity of the Biofield Energy Treated magnesium gluconate compared with the control sample.

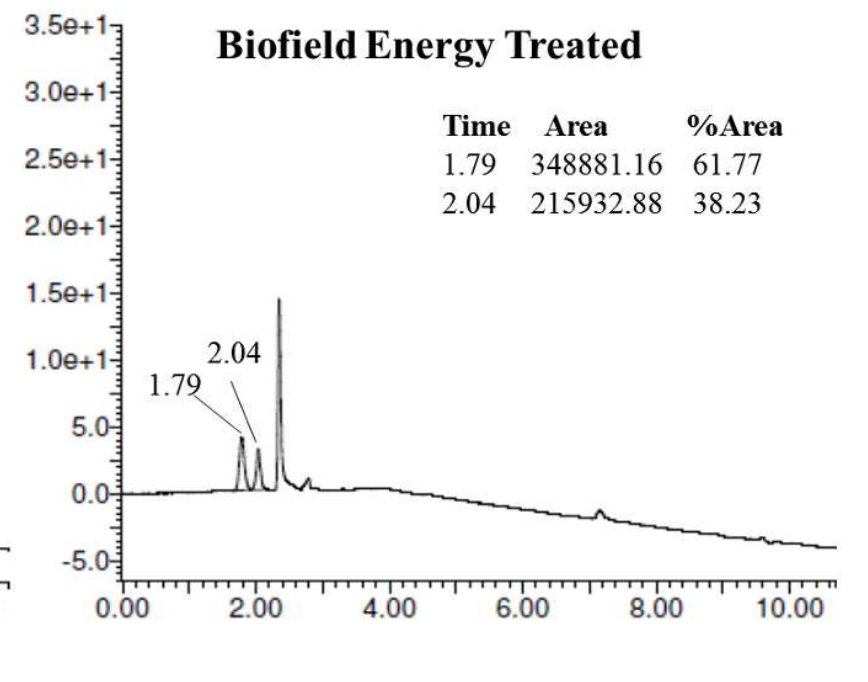

Figure 1. Total ion chromatograms (TIC) of the control and Biofield Energy Treated magnesium gluconate using The Waters ${ }^{\circledR}$ ACQUITY UPLC.

The ESI-MS spectra of both the control and Biofield Energy Treated samples are presented in Figure 2 and 3. The ESI-MS (+ve ion mode) spectra of both the control and Biofield Energy Treated magnesium gluconate at $R_{t}$ of 2.1 minutes (Figure 2) indicated the presence of the mass for protonated magnesium gluconate ion at $m / z 415[\mathrm{M}+\mathrm{H}]^{+}$ (calculated for $\mathrm{C}_{12} \mathrm{H}_{23} \mathrm{MgO}_{14}{ }^{+}, 415$ ). Adduct of the magnesium gluconate with methanol (pseudo molecular ion) was found at $\mathrm{m} / \mathrm{z} 447\left[\mathrm{M}+\mathrm{CH}_{3} \mathrm{OH}+\mathrm{H}\right]^{+}$(calculated for $\mathrm{C}_{13} \mathrm{H}_{27} \mathrm{MgO}_{15}{ }^{+}, 447$ ). Adducts formation, either with solvents (i.e. methanol), alkali or metal ions or other contaminating components are frequently observed in the ESI analysis [47, 48]. 

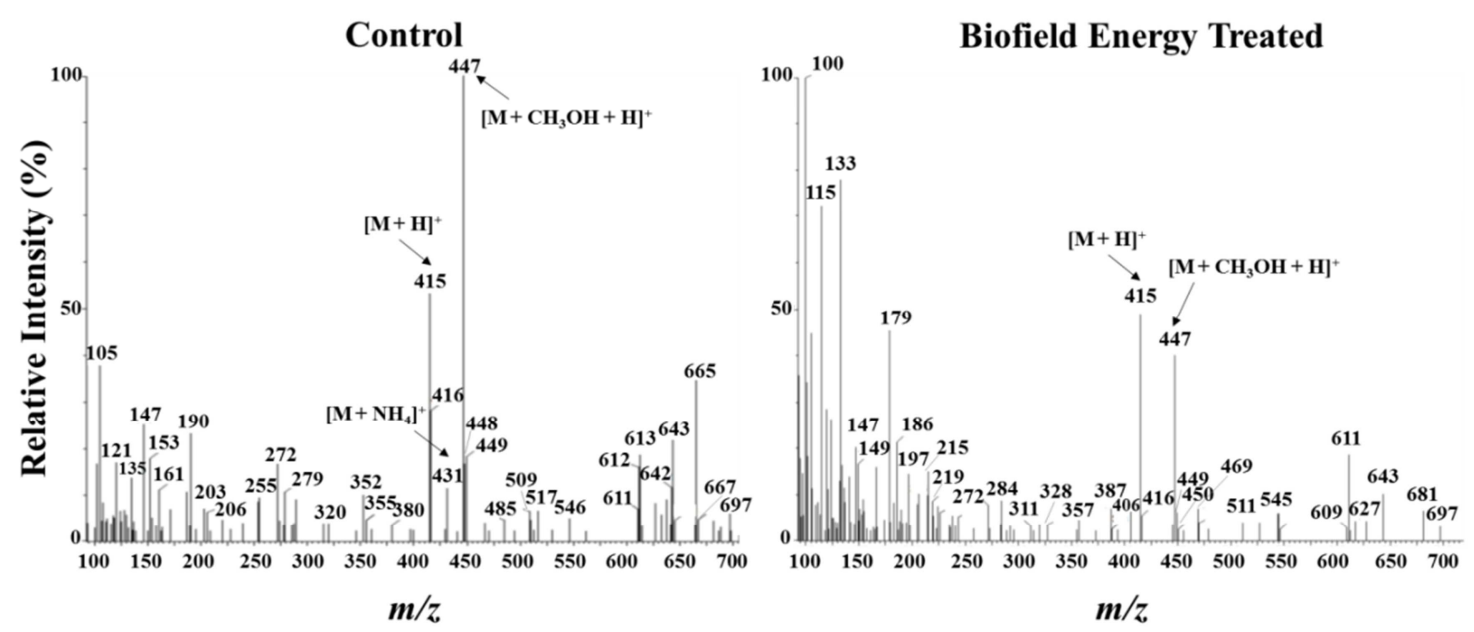

Figure 2. The ESI-MS (+ve ion mode) spectra of the control and Biofield Energy Treated magnesium gluconate.
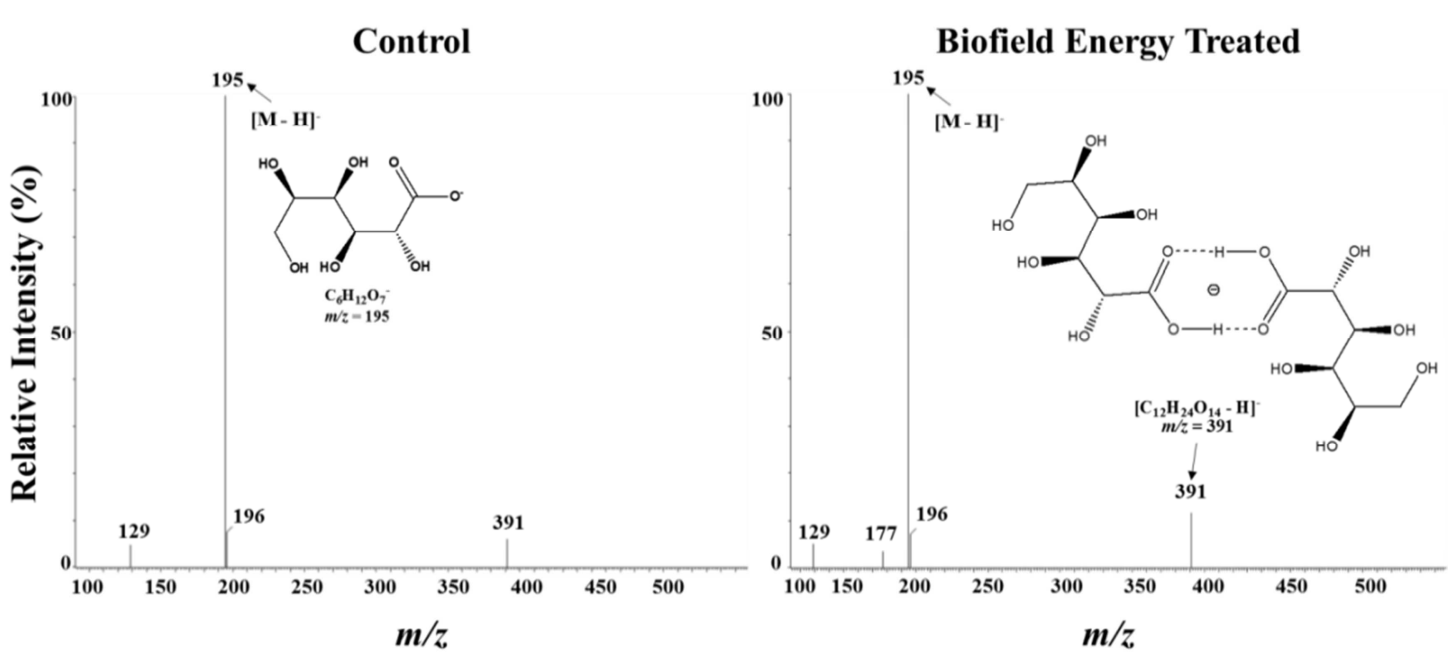

Figure 3. The ESI-MS (-ve ion mode) spectra of the control and Biofield Energy Treated magnesium gluconate.

The pseudo molecular ion magnesium gluconate at $\mathrm{m} / \mathrm{z}$ 447 displayed $100 \%$ relative intensity in the control sample, while the fragment ion peak at $m / z 100$ exhibited the $100 \%$ relative peak intensity in the Biofield Energy Treated sample. The notable fragment ion peaks in the lower region of the molecular ion at $\mathrm{m} / \mathrm{z} 415$ were observed in the ESI-MS spectrum of the control sample at $\mathrm{m} / \mathrm{z} 380,279,272,255$, $206,190,161,153,147,135,121$, and 105, due to the successive removal of water and alkyl groups from $[\mathrm{M}+\mathrm{H}]^{+}$ and consequently, the internal molecular rearrangement, corresponded to the following proposed molecular formula $\mathrm{C}_{12} \mathrm{H}_{20} \mathrm{MgO}_{12}{ }^{+}, \mathrm{C}_{8} \mathrm{H}_{15} \mathrm{MgO}_{9}^{+}, \mathrm{C}_{9} \mathrm{H}_{12} \mathrm{MgO}_{8}^{+}, \mathrm{C}_{8} \mathrm{H}_{7} \mathrm{MgO}_{8}^{+}$, $\mathrm{C}_{8} \mathrm{H}_{6} \mathrm{MgO}_{5}{ }^{2+}, \quad \mathrm{C}_{6} \mathrm{H}_{6} \mathrm{O}_{7}^{+}, \quad \mathrm{C}_{6} \mathrm{H}_{9} \mathrm{O}_{5}^{+}, \quad \mathrm{C}_{5} \mathrm{H}_{13} \mathrm{O}_{5}^{+}, \quad \mathrm{C}_{5} \mathrm{H}_{7} \mathrm{O}_{5}^{+}$, $\mathrm{C}_{5} \mathrm{H}_{11} \mathrm{O}_{4}^{+}, \mathrm{C}_{4} \mathrm{H}_{9} \mathrm{O}_{4}^{+}$, and $\mathrm{C}_{4} \mathrm{H}_{9} \mathrm{O}_{3}^{+}$, respectively as shown in Figure 4. The peak at $m / z$ 431, which was due to the magnesium gluconate adduct with the ammonium ion was only found in the control sample. This ammonium adduct formation might be due to the usage of ammonium acetate with water as mobile phase $[47,48]$. The other major ions in the higher $\mathrm{m} / \mathrm{z}$ region of the control ESI-MS spectrum (Figure 2) were found at $m / z 613,643$ and 665. These mass indicated for the mass of the magnesium gluconate chelate with one gluconate ion through coordinate covalent bond $\left(\mathrm{C}_{18} \mathrm{H}_{33} \mathrm{MgO}_{21}, 609\right)$ as shown in Figure 4. But it existed in three different pseudo-molecular ions. First pseudomolecular ion was at $\mathrm{m} / \mathrm{z} 613$ (calcd for $\mathrm{C}_{18} \mathrm{H}_{37} \mathrm{MgO}_{21}{ }^{4+}$, 613). The second pseudo-molecular ion was due to the adduct formation with methanol at $\mathrm{m} / \mathrm{z} 643$ (calcd for $\left.\mathrm{C}_{19} \mathrm{H}_{38} \mathrm{MgO}_{22}{ }^{+}, 643\right)$. The last pseudo-molecular ion was at $m / z 665$ (calcd for $\mathrm{C}_{19} \mathrm{H}_{37} \mathrm{Mg}_{2} \mathrm{O}_{22}{ }^{+}$, 665) due to the adduct formation of $\mathrm{C}_{18} \mathrm{H}_{33} \mathrm{MgO}_{21}$ with one $\mathrm{Mg}^{++}$atom as well as with methanol. Consequently, the characteristic fragment ion peaks in the ESI-MS spectrum of Biofield Energy Treated sample were observed at $\mathrm{m} / \mathrm{z} 387,357,284,272,219,197$, $179,147,133,115$, and 100 , which corresponded to the following proposed molecular formula $\mathrm{C}_{12} \mathrm{H}_{27} \mathrm{MgO}_{12}{ }^{+}$, $\mathrm{C}_{11} \mathrm{H}_{25} \mathrm{MgO}_{11}^{+}, \mathrm{C}_{8} \mathrm{H}_{20} \mathrm{MgO}_{9}^{+}, \mathrm{C}_{9} \mathrm{H}_{12} \mathrm{MgO}_{8}^{+}, \mathrm{C}_{6} \mathrm{H}_{11} \mathrm{MgO}_{7}^{+}$, $\mathrm{C}_{6} \mathrm{H}_{13} \mathrm{O}_{7}^{+}, \mathrm{C}_{6} \mathrm{H}_{11} \mathrm{O}_{6}^{+}, \mathrm{C}_{5} \mathrm{H}_{7} \mathrm{O}_{5}^{+}, \mathrm{C}_{5} \mathrm{H}_{9} \mathrm{O}_{4}^{+}, \mathrm{C}_{4} \mathrm{H}_{3} \mathrm{O}_{4}^{+}$, and $\mathrm{C}_{4} \mathrm{H}_{4} \mathrm{O}_{3}{ }^{2+}$ respectively (Figure 4 ). The prominent ions observed in the higher $\mathrm{m} / \mathrm{z}$ region of the Biofield Energy Treated ESI-MS spectrum (Figure 2) were at $\mathrm{m} / \mathrm{z} 611$ and 643 corresponding to the molecular formula $\mathrm{C}_{18} \mathrm{H}_{35} \mathrm{MgO}_{21}{ }^{+}$ and $\mathrm{C}_{19} \mathrm{H}_{38} \mathrm{MgO}_{22}{ }^{+}$that was due to the magnesium gluconate chelate with one gluconate ion. 


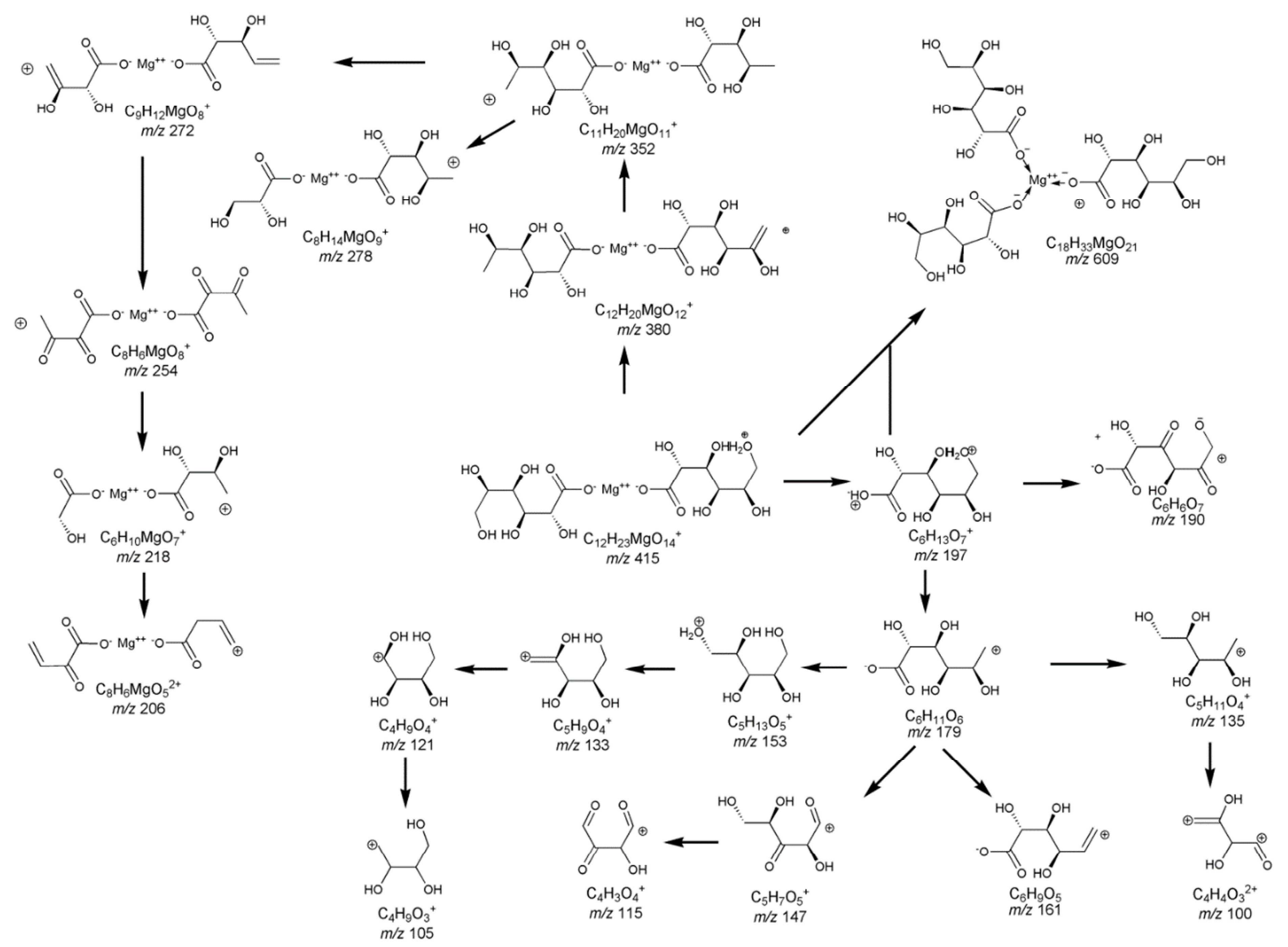

Figure 4. Proposed fragmentation pathway of magnesium gluconate.

Similarly, the ESI-MS (-ve ion mode) spectra of magnesium gluconate of both the control and Biofield Energy Treated samples found at $\mathrm{R}_{\mathrm{t}}$ of 1.8 minutes revealed the presence of gluconate ion at $m / z 195[\mathrm{M}-\mathrm{H}]^{-}$(calculated for $\mathrm{C}_{6} \mathrm{H}_{11} \mathrm{O}_{7}^{-}$) 195 with $100 \%$ base peak intensity. A dimeric form of the gluconate ion was found at $m / z 391[2 \mathrm{M}-\mathrm{H}]^{-}$ (calculated for $\mathrm{C}_{12} \mathrm{H}_{23} \mathrm{O}_{14}{ }^{-}, 391$ ) both in the control and Biofield Energy Treated samples. Overall, from the above data, it can be concluded that the fragmentation pattern of the Biofield Energy Treated magnesium gluconate was significantly altered compared with the control sample. From the analysis, the pseudo molecular ion formation found less in case of the Biofield Energy Treated sample compared with the control sample in solution.

\subsection{Isotopic Abundance Ratio Analysis}

The molecular formula of magnesium gluconate is $\mathrm{C}_{12} \mathrm{H}_{22} \mathrm{MgO}_{14}$. The LC-MS spectra of both the control and Biofield Energy Treated samples indicated the presence of the mass for protonated molecular ion at $\mathrm{m} / \mathrm{z} 415$ $\left(\mathrm{C}_{12} \mathrm{H}_{23} \mathrm{MgO}_{14}{ }^{+}\right)$showing $53.31 \%$ (control) and $48.73 \%$ (Biofield Energy Treated) relative intensity. The relative abundances of an isotopic peak are the contributions of several different isotopes and its composition to the same peak [43]. The theoretical calculation of $\mathrm{P}_{\mathrm{M}+1}$ for the protonated magnesium gluconate was presented as below:
$\mathrm{P}\left({ }^{13} \mathrm{C}\right)=\left[(12 \times 1.1 \%) \times 53.31 \%\right.$ (the actual size of the $\mathrm{M}^{+}$ peak) $] / 100 \%=7.04 \%$

$\mathrm{P}\left({ }^{2} \mathrm{H}\right)=[(23 \times 0.015 \%) \times 53.31 \%] / 100 \%=0.18 \%$

$\mathrm{P}\left({ }^{17} \mathrm{O}\right)=[(14 \times 0.04 \%) \times 53.31 \%] / 100 \%=0.30 \%$

$\mathrm{P}\left({ }^{25} \mathrm{Mg}\right)=[(1 \times 12.66 \%) \times 53.31 \%] / 100 \%=6.75 \%$

$\mathrm{P}_{\mathrm{M}+1}$ i.e. ${ }^{13} \mathrm{C},{ }^{2} \mathrm{H},{ }^{17} \mathrm{O}$, and ${ }^{25} \mathrm{Mg}$ contributions from $\mathrm{C}_{12} \mathrm{H}_{23} \mathrm{MgO}_{14}{ }^{+}$to $m / z 416=14.27 \%$

Thus, the probability to $A+1$ elements having an isotope that has one mass unit heavier than the most abundant isotope (i.e. ${ }^{13} \mathrm{C},{ }^{2} \mathrm{H},{ }^{17} \mathrm{O}$, and ${ }^{25} \mathrm{Mg}$ ) contributions to the mass of the isotopic molecular ion $\left[(\mathrm{M}+1)^{+}\right]$. In general, the deuterium did not contribute much to any isotopic mass, because the natural abundance of deuterium is too small relative to the natural abundances of carbon, oxygen and magnesium isotopes [43-45]. Hence, ${ }^{13} \mathrm{C}$ and ${ }^{25} \mathrm{Mg}$ have the major contributions from magnesium gluconate and magnesium gluconate to the isotopic peaks. The percentage change in isotopic abundance ratio of $\mathrm{P}_{\mathrm{M}+1} / \mathrm{P}_{\mathrm{M}}$ for magnesium gluconate in the Biofield Energy Treated and control samples are presented in Table 2. The isotopic abundance ratio of $\mathrm{P}_{\mathrm{M}+1} / \mathrm{P}_{\mathrm{M}}$ in the Biofield Energy Treated magnesium gluconate was decreased by $79.24 \%$ compared with the control sample (Table 2). ${ }^{13} \mathrm{C}$ and ${ }^{25} \mathrm{Mg}$ contributions from $\mathrm{C}_{12} \mathrm{H}_{23} \mathrm{MgO}_{14}{ }^{+}$to $\mathrm{m} / z 415$ in the Biofield Energy Treated sample were reduced compared with the control sample. 
Table 2. Isotopic abundance analysis result of the control and Biofield Energy Treated magnesium gluconate.

\begin{tabular}{lll}
\hline Parameter & $\begin{array}{l}\text { Control } \\
\text { sample }\end{array}$ & $\begin{array}{l}\text { Biofield Energy } \\
\text { Treated sample }\end{array}$ \\
\hline $\mathrm{P}_{\mathrm{M}}$ at $m / z 415(\%)$ & 53.31 & 48.73 \\
$\mathrm{P}_{\mathrm{M}+1}$ at $m / z 416(\%)$ & 28.25 & 5.36 \\
$\mathrm{P}_{\mathrm{M}+1} / \mathrm{P}_{\mathrm{M}}$ & 0.5299 & 0.1100 \\
\% Change of isotopic abundance ratio & & -79.24 \\
( $\mathrm{P}_{\mathrm{M}+1} / \mathrm{P}_{\mathrm{M}}$ ) with repect to the control sample & & \\
\hline
\end{tabular}

$\mathrm{P}_{\mathrm{M}}$ : the relative peak intensity of the parent molecular ion $\left[\mathrm{M}^{+}\right] ; \mathrm{P}_{\mathrm{M}+1}$ : the relative peak intensity of the isotopic molecular ion $\left[(\mathrm{M}+1)^{+}\right]$.

The gluconic acid ion $\left(\mathrm{C}_{6} \mathrm{H}_{11} \mathrm{O}_{7}^{-}\right)$, in the control and Biofield Energy Treated sample showed 100\% relative peak intensity. The abundance of parent molecular ion $\left(\mathrm{P}_{\mathrm{M}}\right)$ was at $\mathrm{m} / \mathrm{z} 196$, and its size was determined solely by the most abundant element composition. $\mathrm{P}_{\mathrm{M}+1}$ can be calculated theoretically and described below:

$\mathrm{P}\left({ }^{13} \mathrm{C}\right)=\left[(6 \times 1.1 \%) \times 100 \%\right.$ (the actual size of the $\mathrm{M}^{+}$ peak) $] / 100 \%=6.60 \%$

$\mathrm{P}\left({ }^{2} \mathrm{H}\right)=[(11 \times 0.015 \%) \times 100 \%] / 100 \%=0.17 \%$

$\mathrm{P}\left({ }^{17} \mathrm{O}\right)=[(7 \times 0.04 \%) \times 100 \%] / 100 \%=0.28 \%$

$\mathrm{P}_{\mathrm{M}+1}$ i.e. ${ }^{13} \mathrm{C},{ }^{2} \mathrm{H}$, and ${ }^{17} \mathrm{O}$ contributions from $\left(\mathrm{C}_{6} \mathrm{H}_{11} \mathrm{O}_{7}\right)^{+}$to $m / z 196=7.05 \%$

The calculated abundance of $\mathrm{P}_{\mathrm{M}+1}(7.05 \%)$ in magnesium gluconate closely matched to the experimental value obtained in the control sample (Table 3). The isotopic abundance ratio of $\mathrm{P}_{\mathrm{M}+1} / \mathrm{P}_{\mathrm{M}}$ in the gluconate ion was significantly decreased by $6.62 \%$ in the Biofield Energy Treated sample compared with the control sample. Hence, ${ }^{13} \mathrm{C},{ }^{2} \mathrm{H}$, and ${ }^{17} \mathrm{O}$ contributions from $\left(\mathrm{C}_{6} \mathrm{H}_{11} \mathrm{O}_{7}\right)^{+}$to $\mathrm{m} / \mathrm{z} 196$ was decreased in the Biofield Energy Treated sample compared with the control sample.

Table 3. LC-MS isotopic abundance analysis result of gluconate ion from the control and Biofield Energy Treated samples.

\begin{tabular}{lll}
\hline Parameter & $\begin{array}{l}\text { Control } \\
\text { sample }\end{array}$ & $\begin{array}{l}\text { Biofield Energy } \\
\text { Treated sample }\end{array}$ \\
\hline $\mathrm{P}_{\mathrm{M}}$ at $m / z 195(\%)$ & 100 & 100 \\
$\mathrm{P}_{\mathrm{M}+1}$ at $m / z 196(\%)$ & 7.55 & 7.05 \\
$\mathrm{P}_{\mathrm{M}+1} / \mathrm{P}_{\mathrm{M}}$ & 0.0755 & 0.0705 \\
\% Change of isotopic abundance ratio & & -6.62 \\
$\left(\mathrm{P}_{\mathrm{M}+1} / \mathrm{P}_{\mathrm{M}}\right)$ with repect to the control sample & & \\
\hline
\end{tabular}

$\mathrm{P}_{\mathrm{M}}$ : the relative peak intensity of the parent molecular ion $\left[\mathrm{M}^{+}\right] ; \mathrm{P}_{\mathrm{M}+1}$ : the relative peak intensity of the isotopic molecular ion $\left[(\mathrm{M}+1)^{+}\right]$.

Briefly, ${ }^{13} \mathrm{C},{ }^{2} \mathrm{H},{ }^{17} \mathrm{O}$, and ${ }^{25} \mathrm{Mg}$ contributions from $\left(\mathrm{C}_{12} \mathrm{H}_{23} \mathrm{MgO}_{14}\right)^{+}$to $\mathrm{m} / z 416$ in the Biofield Energy Treated sample was significantly decreased with respect to the control sample. ${ }^{13} \mathrm{C},{ }^{2} \mathrm{H}$, and ${ }^{17} \mathrm{O}$ contributions from $\left(\mathrm{C}_{6} \mathrm{H}_{11} \mathrm{O}_{7}\right)+$ to $\mathrm{m} / \mathrm{z}$ 196 was also decreased in the Biofield Energy Treated sample comparison with the control sample. Overall, the isotopic abundance ratio of $\mathrm{P}_{\mathrm{M}+1} / \mathrm{P}_{\mathrm{M}}\left({ }^{2} \mathrm{H} /{ }^{1} \mathrm{H}\right.$ or ${ }^{13} \mathrm{C} /{ }^{12} \mathrm{C}$ or ${ }^{17} \mathrm{O} /{ }^{16} \mathrm{O}$ or ${ }^{25} \mathrm{Mg} /{ }^{24} \mathrm{Mg}$ ) in the Biofield Energy Treated magnesium gluconate was significantly decreased compared with the control sample. The alteration in the isotopic abundance ratio could be due to the Biofield Energy Healing Treatment.

Scientific literature reported that the vibrational energy is closely related with the reduced mass $(\mu)$ of the compound and the alteration of the vibrational energy can affect the several characteristics like physicochemical, thermal properties of the molecule $[37,38,52,53]$. Replacement of the isotopic composition of the magnesium gluconate significantly alters the vibrational energy [41, 52, 53]. The vibrational energy depends on the reduced mass $(\mu)$ for a diatomic molecule as shown below (equation 2):

$$
E_{O}=\frac{h}{4 \pi} \sqrt{\frac{f}{\mu}}
$$

Where, $\mathrm{E}_{0}=$ the vibrational energy of a harmonic oscillator at absolute zero or zero point energy; $f=$ force constant

$$
\mu=\text { reduced mass }=\frac{m_{a} m_{a}}{m_{a}+m_{a}}
$$

Where $m_{a}$ and $m_{b}$ are the masses of the constituent atoms.

The reduced mass $(\mu)$ of some of the probable isotopic bonds were calculated for magnesium gluconate and its possible fragmentations, and the results showed that $\mu$ of heavier isotopes $\left[\right.$ i.e. ${ }^{13} \mathrm{C}-{ }^{12} \mathrm{C}(\mu=6.24),{ }^{2} \mathrm{H}^{-12} \mathrm{C}(\mu=1.71),{ }^{16} \mathrm{O}$ ${ }^{13} \mathrm{C}(\mu=7.17),{ }^{17} \mathrm{O}-{ }^{12} \mathrm{C}(\mu=7.03),{ }^{16} \mathrm{O}-{ }^{2} \mathrm{H}(\mu=1.78),{ }^{25} \mathrm{Mg}^{-16} \mathrm{O}$ $(\mu=9.76)$, and $\left.{ }^{24} \mathrm{Mg}{ }^{17} \mathrm{O}(\mu=9.95), e t c.\right]$ were increased than the normal bond $\left[\right.$ i.e. ${ }^{12} \mathrm{C}-{ }^{12} \mathrm{C}(\mu=6),{ }^{1} \mathrm{H}-{ }^{12} \mathrm{C}(\mu=0.92),{ }^{16} \mathrm{O}-{ }^{12} \mathrm{C}$ $(\mu=6.86),{ }^{16} \mathrm{O}-{ }^{1} \mathrm{H}(\mu=0.94)$ and $\left.{ }^{24} \mathrm{Mg}-{ }^{16} \mathrm{O}(\mu=9.60)\right]$ (Table 4).

Table 4. Possible isotopic bonds, reduced mass and their effect on the vibrational energy in magnesium gluconate.

\begin{tabular}{llll}
\hline Isotope bond & Isotope type & $\begin{array}{l}\text { Reduced mass }(\boldsymbol{\mu}) \\
\left(\mathbf{m}_{\mathbf{A}} \mathbf{m}_{\mathbf{B}} /\left(\mathbf{m}_{\mathbf{A}}+\mathbf{m}_{\mathbf{B}}\right)\right.\end{array}$ & $\begin{array}{l}\text { Zero point vibrational } \\
\text { energy }\left(\boldsymbol{E}_{\boldsymbol{0}}\right)\end{array}$ \\
\hline${ }^{12} \mathrm{C}-{ }^{12} \mathrm{C}$ & Lighter & 6.00 & Higher \\
${ }^{13} \mathrm{C}-{ }^{12} \mathrm{C}$ & Heavier & 6.26 & Smaller \\
${ }^{1} \mathrm{H}-{ }^{12} \mathrm{C}$ & Lighter & 0.92 & Higher \\
${ }^{2} \mathrm{H}-{ }^{12} \mathrm{C}$ & Heavier & 1.04 & Smaller \\
${ }^{16} \mathrm{O}-{ }^{12} \mathrm{C}$ & Lighter & 6.86 & Higher \\
${ }^{16} \mathrm{O}-{ }^{13} \mathrm{C}$ & Heavier & 7.17 & Smaller \\
${ }^{17} \mathrm{O}-{ }^{12} \mathrm{C}$ & Heavier & 7.03 & Smaller \\
${ }^{16} \mathrm{O}-{ }^{1} \mathrm{H}$ & Lighter & 0.94 & Higher \\
${ }^{16} \mathrm{O}-{ }^{2} \mathrm{H}$ & Heavier & 1.78 & Smaller \\
${ }^{24} \mathrm{Mg}-{ }^{16} \mathrm{O}$ & Lighter & 9.60 & Higher \\
${ }^{25} \mathrm{Mg}-{ }^{16} \mathrm{O}$ & Heavier & 9.76 & Smaller \\
${ }^{24} \mathrm{Mg}-{ }^{17} \mathrm{O}$ & Heavier & 9.95 & Smaller \\
\hline
\end{tabular}

$\mathrm{m}_{\mathrm{A}}$ : mass of atom $\mathrm{A} ; \mathrm{m}_{\mathrm{B}}$ : mass of atom $\mathrm{B}$, here $\mathrm{A}$ and $\mathrm{B}$ may be $\mathrm{C}$ or $\mathrm{H}$ or $\mathrm{O}$ or $\mathrm{Mg}$.

The alteration in the isotopic abundance ratio of ${ }^{13} \mathrm{C} /{ }^{12} \mathrm{C}$ for $\mathrm{C}-\mathrm{O} ;{ }^{2} \mathrm{H} /{ }^{1} \mathrm{H}$ for $\mathrm{C}-\mathrm{H}$ and $\mathrm{O}-\mathrm{H}$ bonds; ${ }^{17} \mathrm{O} /{ }^{16} \mathrm{O}$ for $\mathrm{C}-\mathrm{O}$ bond; ${ }^{25} \mathrm{Mg} /{ }^{24} \mathrm{Mg}$, and ${ }^{17} \mathrm{O} /{ }^{16} \mathrm{O}$ for $\mathrm{Mg}-\mathrm{O}$ bond has the significant impact on the ground state vibrational energy of the molecule due to the higher reduced mass $(\mu)$ as shown in the Table 4 that leads to the isotope effects of the molecule.

Mass spectroscopic analysis of the several organic compounds revealed that the isotopic abundance of $[\mathrm{M}+1]^{+}$ ions were decreased, thereby suggesting the change in number of neutrons in the molecule. It was then postulated to the alterations in atomic mass and atomic charge through the possible mediation of neutrino oscillation [52-54]. Thus, it is assumed that The Trivedi Effect ${ }^{\circledR}$ - Biofield Energy Healing might provide the required energy for the neutrino 
oscillations. The changes of neutrinos inside the molecule in turn modified the particle size, chemical reactivity, density, thermal behavior, selectivity, binding energy, etc. [44, 54].

Kinetic isotope effect that is resultant from the variation in the isotopic abundance ratio of one of the atoms in the reactants in a chemical reaction is very useful to study the reaction mechanism as well as for understanding the enzymatic transition state and all aspects of enzyme mechanisms that is supportive for designing enormously effective and specific inhibitors [41, 49, 51]. As magnesium is an essential cofactor for various enzymatic reactions, the Biofield Energy Treated magnesium gluconate that had altered isotopic abundance ratio might be useful for the study of enzyme mechanism as well as assist in the designing of novel potent enzyme inhibitors.

\subsection{Nuclear Magnetic Resonance Spectroscopy $\left({ }^{1} \mathrm{H}\right.$ and ${ }^{13} \mathrm{C}$ NMR) Analysis}

The ${ }^{1} \mathrm{H}$ and ${ }^{13} \mathrm{C}$ NMR spectra of the control and Biofield Energy Treated magnesium gluconate are shown in Figures 5a-d. NMR assignments of the control and Biofield Energy Treated magnesium gluconate are presented in the Table 5. The structure of magnesium gluconate contain a large number of $\mathrm{OH}$ groups and the hydroxyl protons have no signal in the ${ }^{1} \mathrm{H}$ NMR spectra because these protons are replaced by deuterium when deuterated water $\left(\mathrm{D}_{2} \mathrm{O}\right)$ was used as solvent for spectra recording The signals for the protons signals for $\mathrm{CH}_{2}$ and $\mathrm{CH}$ groups of the control and Biofield Energy Treated magnesium gluconate were in the range of $\delta 3.54-4.06$ ppm and $\delta$ 3.54-4.07 ppm respectively, which complies the reported proton spectrum of sodium gluconate [46].

Table 5. ${ }^{1} \mathrm{H}$ and ${ }^{13} \mathrm{C}$ NMR assignments of the both control and Biofield Energy Treated of magnesium gluconate.

\begin{tabular}{|c|c|c|c|c|c|}
\hline \multirow{2}{*}{ Position } & \multicolumn{3}{|c|}{${ }^{1}$ H NMR $\delta(p p m)$} & \multicolumn{2}{|c|}{ 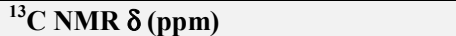 } \\
\hline & Number & Control & Biofield Energy Treated & Control & Biofield Energy Treated \\
\hline $1,1^{\prime}$ & $4 \mathrm{H}^{*}$ & $\begin{array}{l}3.74(\mathrm{br} \mathrm{s}) \\
3.54-3.59\left(2 \mathrm{H}^{*}, \mathrm{~m}\right)\end{array}$ & $\begin{array}{l}3.73(\mathrm{br} \mathrm{s}) \\
3.54-3.57\left(2 \mathrm{H}^{*}, \mathrm{~m}\right)\end{array}$ & 62.60 & 62.43 \\
\hline $2,2^{\prime}$ & $2 \mathrm{H}^{*}$ & 3.67 (br s) & $3.66(\mathrm{br} \mathrm{s})$ & 70.84 & 70.67 \\
\hline $3,3^{\prime}$ & $2 \mathrm{H}^{*}$ & 3.71 (br s) & 3.69 (br s) & 71.17 & 70.96 \\
\hline $4,4^{\prime}$ & $2 \mathrm{H}$ & $3.95(\mathrm{br} \mathrm{s})$ & $3.95(\mathrm{br} \mathrm{s})$ & 72.42 & 72.24 \\
\hline $5,5^{\prime}$ & $2 \mathrm{H}$ & $4.06(\mathrm{br} \mathrm{s})$ & 4.07 (br s) & 74.01 & 73.90 \\
\hline $6,6^{\prime}$ & -- & -- & -- & 178.44 & 178.38 \\
\hline
\end{tabular}

s: singlet; br: broad; m: multiplet; * these assignments can be switched.

The signals for the carbon signals for $\mathrm{CO}, \mathrm{CH}_{2}$ and $\mathrm{CH}$ groups in the ${ }^{13} \mathrm{C}$ NMR spectra of the control and Biofield Energy Treated magnesium gluconate were in the range of $\delta$ 62.60-178.44 ppm and $\delta 62.43-178.44$ ppm, respectively. Thus, the proton and carbon signals for $\mathrm{CH}, \mathrm{CH}_{2}$ and $\mathrm{CO}$ groups in the proton and carbon NMR spectra of the control and the Biofield Energy Treated samples were found almost similar. It was then concluded that the structure of the magnesium gluconate was remained unaltered due to the Biofield Energy Healing Treatment.

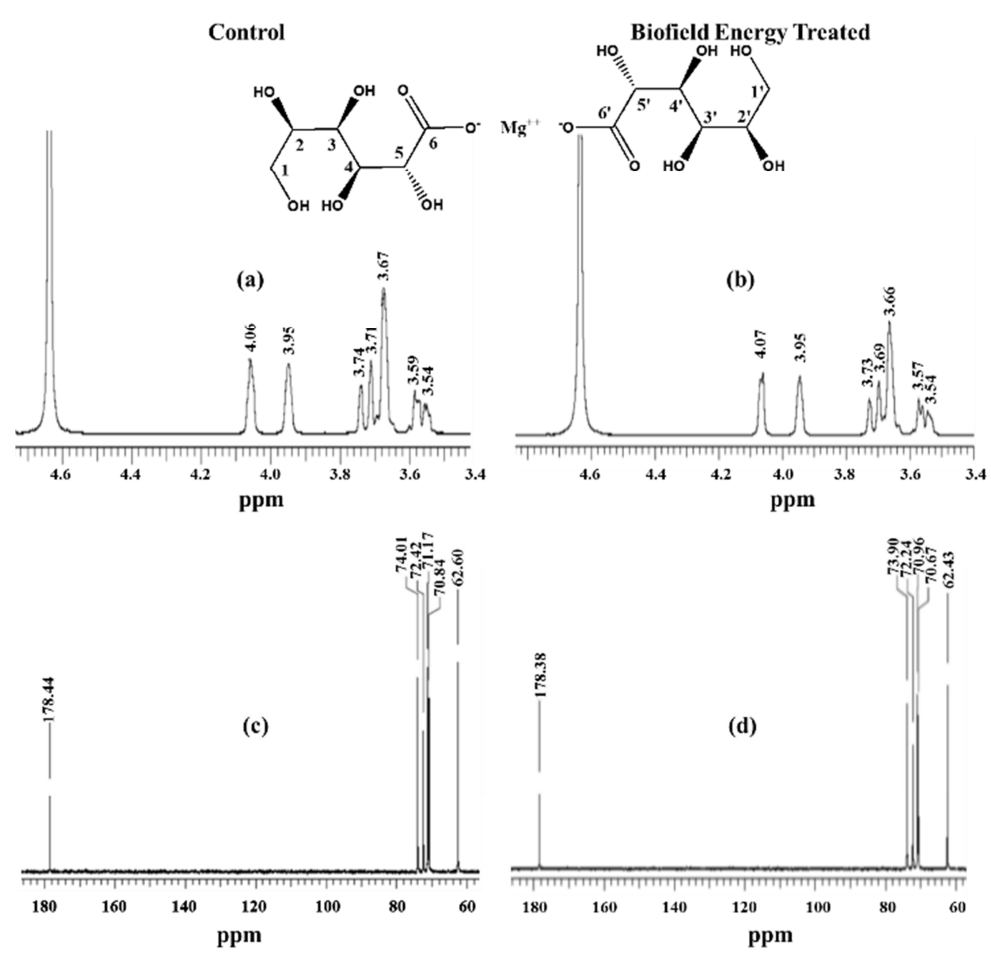

Figure 5. ${ }^{1} \mathrm{H} N M R$ spectra of the (a) control, (b) the Biofield Energy Treated, ${ }^{13} \mathrm{C} N M R$ spectra of the (c) control, and (d) the Biofield Energy Treated magnesium gluconate. 


\section{Conclusions}

LC-ESI-MS analysis indicated that magnesium gluconate in the solution might be existed in situ of three forms, magnesium gluconate, gluconic acid and a chelate form of magnesium gluconate with the gluconic acid by the coordinate covalent bond. The total ion chromatogram (TIC) of the control sample showed two peaks at $R_{t}$ of 1.81 and 2.06 minutes, whereas The Trivedi Effect ${ }^{\circledR}$ treated sample displayed these peaks at $\mathrm{R}_{\mathrm{t}}$ of 1.79 and 2.04 minutes. The ESI-MS spectra of the control and the treated samples revealed the presence of the mass for magnesium gluconate ion in two forms at $\mathrm{m} / \mathrm{z} 447$ (adduct form with methanol) and 415 (protonated ion) in positive ionization mode. But, it showed the mass for the gluconate ion at $\mathrm{m} / \mathrm{z} 195$ in the negative ionization mode. The fragmentation pattern of magnesium gluconate in the treated sample was significantly altered as compared to the control sample. Consequently, the LC-ESI-MS based isotopic abundance ratio analysis indicated that the $\mathrm{P}_{\mathrm{M}+1} / \mathrm{P}_{\mathrm{M}}\left({ }^{2} \mathrm{H} /{ }^{1} \mathrm{H}\right.$ or ${ }^{13} \mathrm{C} /{ }^{12} \mathrm{C}$ or ${ }^{17} \mathrm{O} /{ }^{16} \mathrm{O}$ or ${ }^{25} \mathrm{Mg} /{ }^{24} \mathrm{Mg}$ ) in the Biofield Energy Treated magnesium gluconate ion at $\mathrm{m} / \mathrm{z} 415$ was significantly decreased by $79.24 \%$ compared with the control sample. Similarly, the isotopic abundance ratio of $\mathrm{P}_{\mathrm{M}+1} / \mathrm{P}_{\mathrm{M}}\left({ }^{2} \mathrm{H} /{ }^{1} \mathrm{H}\right.$ or ${ }^{13} \mathrm{C} /{ }^{12} \mathrm{C}$ or ${ }^{17} \mathrm{O} /{ }^{16} \mathrm{O}$ ) in gluconate was decreased by $6.62 \%$ in the treated sample compared with the control sample. Briefly, ${ }^{13} \mathrm{C},{ }^{2} \mathrm{H}$, ${ }^{17} \mathrm{O}$, and ${ }^{25} \mathrm{Mg}$ contributions from $\left(\mathrm{C}_{12} \mathrm{H}_{23} \mathrm{MgO}_{14}\right)^{+}$to $\mathrm{m} / \mathrm{z} 416$ in the Biofield Energy Treated sample was significantly decreased with respect to the control sample. ${ }^{13} \mathrm{C},{ }^{2} \mathrm{H}$, and ${ }^{17} \mathrm{O}$ contributions from $\left(\mathrm{C}_{6} \mathrm{H}_{11} \mathrm{O}_{7}\right)^{+}$to $\mathrm{m} / z 196$ was also decreased in the treated sample in comparison with the control sample. The treated sample might exhibit isotope effects such as altered physicochemical and thermal properties, rate of the reaction, selectivity and binding energy due to its changed isotopic abundance ratio of $\mathrm{P}_{\mathrm{M}+1} / \mathrm{P}_{\mathrm{M}}$ compared with the control sample. The treated magnesium gluconate might be helpful to understand the enzymatic reactions as well as design the novel potent enzyme inhibitors by using its kinetic isotope effects. Besides, The Trivedi Effect ${ }^{\mathbb{B}}$ - Energy of Consciousness Healing Treatment, could be a useful approach in the design of better nutraceutical and/or pharmaceutical formulations that can offer significant therapeutic responses against various diseases such as diabetes mellitus, allergies and septic shock, stress-related disorders like sleep disorder, insomnia, anxiety, depression, Attention Deficit Disorder (ADD), Attention Deficit Hyperactive Disorder (ADHD), mental restlessness (mind chattering), brain frog, low libido, impotency, lack of motivation, mood swings, fear of the future, confusion, migraines, headaches, forgetfulness, overwhelm, loneliness, worthlessness, indecisiveness, frustration, irritability, chronic fatigue, obsessive/compulsive behavior and panic attacks, inflammatory diseases and immunological disorders like Lupus, Systemic Lupus Erythematosus, Hashimoto Thyroiditis, Type 1 Diabetes, Asthma, Chronic peptic ulcers, Tuberculosis, Hepatitis, Chronic active hepatitis, Celiac
Disease (gluten-sensitive enteropathy), Addison Disease, Crohn's disease, Graves' Disease, Pernicious and Aplastic Anemia, Sjogren Syndrome, Irritable Bowel Syndrome (IBS), Multiple Sclerosis, Rheumatoid arthritis, Chronic periodontitis, Ulcerative colitis, Chronic sinusitis, Myasthenia Gravis, Atherosclerosis, Vasculitis, Dermatitis, Diverticulitis, Rheumatoid Arthritis, Reactive Arthritis, Alopecia Areata, Psoriasis, Scleroderma, Fibromyalgia, Chronic Fatigue Syndrome and Vitiligo, aging-related diseases like cardiovascular disease, arthritis, cancer, Alzheimer's disease, dementia, cataracts, osteoporosis, diabetes, hypertension, glaucoma, hearing loss, Parkinson's Disease, Huntington's Disease, Prion Disease, Motor Neurone Disease, Spinocerebellar Ataxia, Spinal muscular atrophy, Amyotrophic lateral sclerosis, Friedreich's Ataxia and Lewy Body Disease; chronic infections and much more.

\section{Abbreviations}

$A$ : Element; EI: Electron ionization; ESI: electrospray ionization; IAR: Isotopic abundance ratio; LC-MS: Liquid chromatography-mass spectrometry, PDA: Photodiode Array; NMR: Nuclear magnetic resonance spectroscopy; $\mathrm{P}_{\mathrm{M}}$ : The relative peak intensity of the parent molecular ion $\left[\mathrm{M}^{+}\right]$; $\mathrm{P}_{\mathrm{M}+1}$ : The relative peak intensity of isotopic molecular ion $\left.\left[(\mathrm{M}+1)^{+}\right]\right) ; \mathrm{R}_{\mathrm{t}}$ : Retention time, TIC: Total ion chromatogram, UPLC: Ultra-performance liquid chromatography.

\section{Acknowledgements}

The authors are grateful to GVK Biosciences Pvt. Ltd., Trivedi Science, Trivedi Global, Inc. and Trivedi Master Wellness for their assistance and support during this work.

\section{References}

[1] Heaton FW (1990) Role of magnesium in enzyme systems in metal ions in biological systems, In: Sigel H, Sigel A (Eds.), Volume 26: Compendium on magnesium and its role in biology, nutrition and physiology, Marcel Dekker Inc., New York.

[2] Garfinkel L, Garfinkel D (1985) Magnesium regulation of the glycolytic pathway and the enzymes involved. Magnesium 4: 60-72.

[3] Ramachandran S, Fontanille P, Pandey A, Larroche C (2006) Gluconic acid: Properties, applications and microbial production. Food Technol Biotechnol 44: 185-195.

[4] Gröber U, Schmidt J, Kisters K (2015) Magnesium in prevention and therapy. Nutrients 7: 8199-8226.

[5] William JH, Danziger J (2016) Magnesium deficiency and proton-pump inhibitor use: A clinical review. J Clin Pharmacol 56: 660-668.

[6] Guerrera MP, Volpe SL, Mao JJ (2009) Therapeutic uses of magnesium. Am Fam Physician 80: 157-162. 
[7] Fleming TE, Mansmann Jr HC (1999) Methods and compositions for the prevention and treatment of diabetes mellitus. United States Patent 5871769, 1-10.

[8] Fleming TE, Mansmann Jr HC (1999) Methods and compositions for the prevention and treatment of immunological disorders, inflammatory diseases and infections. United States Patent 5939394, 1-11.

[9] Turner RJ, Dasilva KW, O'Connor C, van den Heuvel C, Vink R (2004) Magnesium gluconate offers no more protection than magnesium sulphate following diffuse trau-matic braininjury in rats. J Am Coll Nutr 23: 541S-544S.

[10] Weglicki WB (2000) Intravenous magnesium gluconate for treatment of conditions caused by excessive oxidative stress due to free radical distribution. United States Patent 6100297, $1-6$.

[11] Martin RW, Martin JN Jr, Pryor JA, Gaddy DK, Wiser WL, Morrison JC (1988) Comparison of oral ritodrine and magnesium gluconate for ambulatory tocolysis. Am J Obstet Gynecol 158: 1440-1445.

[12] Coudray C, Rambeau M, Feillet-Coudray C, Gueux E, Tressol JC, Mazur A, Rayssiguier Y (2005) Study of magnesium bioavailability from ten organic and inorganic $\mathrm{Mg}$ salts in $\mathrm{Mg}$ depleted rats using a stable isotope approach. Magnes Res 18: 215-223.

[13] Stenger VJ (1999) Bioenergetic Fields. Sci Rev Alternative Med 3.

[14] Rogers, M (1989) Nursing: A Science of Unitary Human Beings. In J. P. Riehl-Sisca (ed.) Conceptual Models for Nursing Practice. $3^{\text {rd }}$ Edn. Norwark: Appleton \& Lange.

[15] Rosa L, Rosa E, Sarner L, Barrett S (1998) A close look at therapeutic touch. JAMA- J Am Med Assoc 279: 1005-1010.

[16] Warber SL, Cornelio D, Straughn, J, Kile G (2004) Biofield energy healing from the inside. J Altern Complement Med 10: 1107-1113.

[17] Koithan M (2009) Introducing complementary and alternative therapies. J Nurse Pract 5: 18-20.

[18] Trivedi MK, Branton A, Trivedi D, Nayak G, Gangwar M, Jana S (2015) Agronomic characteristics, growth analysis, and yield response of biofield treated mustard, cowpea, horse gram, and groundnuts. International Journal of Genetics and Genomics 3: 74-80.

[19] Trivedi MK, Branton A, Trivedi D, Nayak G, Gangwar M, Jana $S$ (2015) Evaluation of vegetative growth parameters in biofield treated bottle gourd (Lagenaria siceraria) and Okra (Abelmoschus esculentus). International Journal of Nutrition and Food Sciences. 4: 688-694.

[20] Trivedi MK, Branton A, Trivedi D, Nayak G, Gangwar M, Jana S (2015) Morphological and molecular analysis using RAPD in biofield treated sponge and bitter gourd. American Journal of Agriculture and Forestry 3: 264-270.

[21] Trivedi MK, Branton A, Trivedi D, Nayak G, Bairwa K, Jana S (2015) Physical, thermal, and spectroscopic characterization of biofield energy treated murashige and skoog plant cell culture media. Cell Biology 3: 50-57.

[22] Trivedi MK, Branton A, Trivedi D, Nayak G, Mondal SC, Jana S (2015) Morphological characterization, quality, yield and DNA fingerprinting of biofield energy treated Alphonso mango (Mangifera indica L.). Journal of Food and Nutrition Sciences 3: 245-250.

[23] Trivedi MK, Branton A, Trivedi D, Nayak G, Mondal SC, Jana S (2015) Evaluation of plant growth, yield and yield attributes of biofield energy treated mustard (Brassica juncea) and chick pea (Cicer arietinum) seeds. Agriculture, Forestry and Fisheries 4: 291-295.

[24] Trivedi MK, Branton A, Trivedi D, Nayak G, Saikia G, Jana S (2015) Evaluation of isotopic abundance ratio of naphthalene derivatives after biofield energy treatment using gas chromatography-mass spectrometry. American Journal of Applied Chemistry 3: 194-200.

[25] Trivedi MK, Branton A, Trivedi D, Nayak G, Saikia G, Jana S (2015) Isotopic abundance analysis of biofield treated benzene, toluene and $p$-xylene using gas chromatographymass spectrometry (GC-MS). Mass Spectrom Open Access 1: 102.

[26] Trivedi MK, Branton A, Trivedi D, Nayak G, Saikia G, Jana S (2015) Influence of biofield energy treatment on isotopic abundance ratio in aniline derivatives. Mod Chem Appl 3: 168.

[27] Trivedi MK, Branton A, Trivedi D, Nayak G, Saikia G, Jana S (2015) Quantitative determination of isotopic abundance ratio of ${ }^{13} \mathrm{C},{ }^{2} \mathrm{H}$, and ${ }^{18} \mathrm{O}$ in biofield energy treated ortho and meta toluic acid isomers. American Journal of Applied Chemistry 3: $217-223$.

[28] Trivedi MK, Branton A, Trivedi D, Nayak G, Saikia G, Jana S (2015) Mass Spectrometry Analysis of Isotopic Abundance of ${ }^{13} \mathrm{C},{ }^{2} \mathrm{H}$, or ${ }^{15} \mathrm{~N}$ in biofield energy treated aminopyridine derivatives. American Journal of Physical Chemistry 4: 65-70.

[29] Trivedi MK, Patil S, Shettigar H, Bairwa K, Jana S (2015) Effect of biofield treatment on spectral properties of paracetamol and piroxicam. Chem Sci J 6: 98.

[30] Trivedi MK, Patil S, Shettigar H, Bairwa K, Jana S (2015) Spectroscopic characterization of biofield treated metronidazole and tinidazole. Med chem 5: 340-344.

[31] Trivedi MK, Patil S, Shettigar H, Bairwa K, Jana S, Bairwa K (2015) Spectroscopic characterization of chloramphenicol and tetracycline: An impact of biofield. Pharm Anal Acta 6: 395.

[32] Trivedi MK, Patil S, Shettigar H, Gangwar M, Jana S (2015) In vitro evaluation of biofield treatment on cancer biomarkers involved in endometrial and prostate cancer cell lines. J Cancer Sci Ther 7: 253-257.

[33] Trivedi MK, Patil S, Shettigar H, Mondal SC, Jana S (2015) The potential impact of biofield treatment on human brain tumor cells: A time-lapse video microscopy. J Integr Oncol 4: 141.

[34] Trivedi MK, Branton A, Trivedi D, Shettigar H, Nayak G, Mondal SC, Jana S (2015) Antibiogram, biochemical reactions and genotyping characterization of biofield treated Staphylococcus aureus. American Journal of BioScience 3: 212-220.

[35] Trivedi MK, Branton A, Trivedi D, Nayak G, Mondal SC, Jana S (2015) Antimicrobial sensitivity, biochemical characteristics and biotyping of Staphylococcus saprophyticus: An impact of biofield energy treatment. J Women's Health Care 4: 271. 
[36] Trivedi MK, Branton A, Trivedi D, Nayak G, Shettigar H, Gangwar M, Jana S (2015) Antibiogram of multidrugresistant isolates of Pseudomonas aeruginosa after biofield treatment. J Infect Dis Ther 3: 244.

[37] Trivedi MK, Branton A, Trivedi D, Nayak G, Panda P, Jana S (2016) Isotopic abundance ratio analysis of 1, 2, 3trimethoxybenzene (TMB) after biofield energy treatment (The Trivedi Effect ${ }^{\mathbb{B}}$ ) using gas chromatography-mass spectrometry. American Journal of Applied Chemistry 4: 132140.

[38] Trivedi MK, Branton A, Trivedi D, Nayak G, Sethi KK, Jana S (2016) Gas chromatography-mass spectrometry based isotopic abundance ratio analysis of biofield energy treated methyl-2-napthylether (Nerolin). American Journal of Physical Chemistry 5: 80-86.

[39] Schellekens RC, Stellaard F, Woerdenbag HJ, Frijlink HW, Kosterink JG (2011) Applications of stable isotopes in clinical pharmacology. Br J Clin Pharmacol 72: 879-897.

[40] Muccio Z, Jackson GP (2009) Isotope ratio mass spectrometry. Analyst 134: 213-222.

[41] Vanhaecke F, Kyser K (2012) Isotopic composition of the elements In Isotopic Analysis: Fundamentals and applications using ICP-MS (1stedn), Edited by Vanhaecke F, Degryse P. Wiley-VCH GmbH \& Co. KGaA, Weinheim.

[42] http://chemwiki.ucdavis.edu/Core/Analytical_Chemistry/Instr umental_Analysis/Mass_Spectrometry/Mass_Spectrometry\% 3A Isotope Effects

[43] Smith RM (2004) Understanding Mass Spectra: A Basic Approach, Second Edition, John Wiley \& Sons, Inc, ISBN 0471-42949-X.

[44] Meija J, Coplen TB, Berglund M, Brand WA, De Bievre P, Groning $\mathrm{M}$, Holden NE, Irrgeher J, Loss RD, Walczyk T, Prohaska T (2016) Isotopic compositions of the elements 2013 (IUPAC technical Report). Pure Appl Chem 88: 293-306.
[45] https://www.ncsu.edu/chemistry/msf/pdf/IsotopicMass Natura lAbundance.pdf.

[46] Nikolic VD, Illic DP, Nikolic LB, Stanojevic LP, Cakic MD, Tacic AD, Ilic-Stojanovic SS (2014) The synthesis and characterization of iron (II) gluconate. Advanced technologies 3: 16-24.

[47] Naegele E (2011) Making your LC Method Compatible with Mass Spectrometry. Agilent Technologies, Inc. Waldbronn, Germany.

[48] Keller BO, Sui J, Young, AB, Whittal RM (2008) Interferences and contaminants encountered in modern mass spectrometry. Analytica Chimica Acta 627: 71-81.

[49] Asperger S (2003) Chemical Kinetics and Inorganic Reaction Mechanisms Springer science + Business media, New York.

[50] Schramm VL (1998) Enzymatic transition states and transition state analog design. Annu Rev Biochem 67: 693-720.

[51] Cleland WW (2003) The use of isotope effects to determine enzyme mechanisms. J Biol Chem 278: 51975-51984.

[52] Trivedi MK, Branton A, Trivedi D, Nayak G, Panda P, Jana S (2016) Determination of isotopic abundance of ${ }^{13} \mathrm{C} /{ }^{12} \mathrm{C}$ or ${ }^{2} \mathrm{H} /{ }^{1} \mathrm{H}$ and ${ }^{18} \mathrm{O} /{ }^{16} \mathrm{O}$ in biofield energy treated 1-chloro-3-nitrobenzene (3-CNB) using gas chromatography-mass spectrometry. Science Journal of Analytical Chemistry 4: 42-51.

[53] Trivedi MK, Branton A, Trivedi D, Nayak G, Sethi KK, Jana S (2016) Evaluation of isotopic abundance ratio in biofield energy treated nitrophenol derivatives using gas chromatography-mass spectrometry. American Journal of Chemical Engineering 4: 68-77.

[54] Trivedi MK, Mohan TRR (2016) Biofield energy signals, energy transmission and neutrinos. American Journal of Modern Physics 5: 172-176. 